\title{
CAUSATIVE FACTORS FOR PREMATURE AGEING
}

\section{Sameer Manohar Joshi ${ }^{1}$, Gandhali Upadhye ${ }^{2}$, Prathamesh Ajit Kotagi ${ }^{3}$}

1. Assistant Professor,

2. Assistant Professor Email: dr.gandhali.b@gmail.com; Ph. No. 9765813261

3. Fourth B.A.M.S. Student ,Email: kotagiamey@gmail.com; Ph. No. 8378848641

Dept. of Panchkarma, Gomantak Ayurved Mahavidyalay and Research Centre, Shiroda . Goa.

* Corresponding author: Email: dr.sameerjoshi@ hotmail.com; Ph.no.9923111910

\begin{abstract}
:
Aging is a complex phenomenon, a sum total of changes that occur in a living organism with the passage of time and lead to decreasing ability to survive stress, increasing functional impairment and growing probability of death. Ayurveda, the Indian traditional medicine, describes aging with great details. Premature aging or "Akale Jarawastha" is the most faced problem specially by young generation now a days and this specialty is surprising $!$
\end{abstract}

One can observe early/premature aging in the present day due to improper life style. This review provides Ayurvedic perspectives on theories of causative factors for premature aging and study of some "Anukta Hetu" can cause premature aging.

Keywords: Jarawasthsa, Akale Jarawastha, Premature Aging, Mand Agni

\section{Introduction :}

Indicative parameters of Jara set by community like Backache, Weak Eyesight, Joint pain, Dementia, Hair fall, Wrinkles tc are seen in today's youth. We can Call it as "Premature Aging". As the subject titled; it is good enough to enlightened with some causes. Here the aim of ayurveda can help. It mainly demonstrate 2 things - 1) Maintain the Health of Healthy person 2) Cure and Improve the Health of patient. For this maintenance and improvement purpose ayurveda told many things like Dincharya, Sadvrutta etc if not followed leads to premature aging like conditions. Other than this Nutrition plays also important role in aging procedure. Also metabolic disorders like DM which affects metabolism and the main thing "Manda Agni" which is root cause of all diseases. In Short in this "Shiryaman 
Sharir" the aging procedure done gradually with the help of Tridosha and Saptdhatu. But production of Asara Dhatu or Vitiation in Dosh/Dhatu/Mala may be the parental cause of Premature Aging.

\section{Aims and Objective:}

Present study was carried out to reevaluate causative factors for premature aging mentioned in classical texts and to find the relationship of lifestyle, occupational and social factors and mental makeup of individuals shows premature aging.

\section{CAUSATIVE FACTORS FOR}

\section{PREMATURE AGING}

Before studying any Vikruta Awastha; first off all we should know the Prakruta Awastha of it.

So before head towards Premature Aging; we should know the normal aging.

Jara/Jaravastha is referred as old age. It has synonyms like Sthavira, Vaardhakya, Jeernaavastha and Vruddha. It is referred as a Svabhavika Vyadhi (naturally occurring disease) [1].

It can be classified into two types further as Kaalaja/Parirakshana krita

(timely aging) and Akaalaja/Aparirakshana krita (early aging) [2].

In case of Kaalaja jara the symptoms of aging appear on appropriate time and there will be simultaneous occurrence of chronological aging and biological aging. In Akaalaja jara, aging occurs before prescribed time due to not taking care of Shareera (body) by following Swasthavritta and Sadvritta. It can be interpreted as biological aging is more intense than chronological aging.

THEORIES OF AGING
1) Svabhavoparama Vada- this is the theory of natural destruction mentioned by Charaka. According to this theory, process of degeneration occurs due to Svabhava (natural) [3]

2) External factors- life span of a person depends on two factors namely Daiva (unknown factor, deeds of previous life) and Purusha Kaarana ( deeds of present life) [4]

3) Kaala (time) - Kaala plays important role in aging process. All things in the world undergo several changes before complete destruction.

This is called as Parinama which is taking place by the influence of Kaala. Thus it can be assumed that Jara is also the result of Kaala

Parinama [5]

4) Shareera Vruddhikara Bhava-Abhava here is mentioning of some of the factors hich promote growth. These factors are saala Yoga

(time), Sabhavasamsiddhi (natural phenomenon), Aharasaustava (food which is taken) and Avighaata (absence of devastating causes). The

gradual reduction or lack of the above factors may lead to reduced growth of a person there by aging occurs.

Premature Aging means nothing but the features or characteristics seen in Jarawastha are seen earlier than its age.

Acharya Sushruta quoted the reference for Akaala Jarawastha in Sutrasthan 24 th adhyay - Vyadhisamuddeshiya adhyay.

$\mathrm{He}$ Mentioned it under Akaalaj Swabhavabalkrut Vyadhi.

\section{- Causes For Premature Aging :}

The root cause for all disease is "Manda Agni" - weak bio-fire. 
The main or parental cause for premature aging is Manda Agni.

The main function of Agni or bio-fire is transformation. In premature aging the function of agni hampered. This can cause due to many agni dushtikar bhava's.

Things which does Agni Dusthi also take part in premature aging process.

Some Important Factors which does Agni Dushti are enlisted as follows...

a) Not Following Ashta Ahar Vidhi Visheshaytan (Charak Vimansthan/Rasavimana Adhyay)

b) Not following Ahar Vidhi Vidhan (Charak Vimansthan/Rasavimana Adhyay)

c) Mithya Aahar - Vihara sevan

These factors does agni dusthi and affects the process of transformation. Agni fails to transform sarabhut ghataka from take food and hence further dhatus also gêt kuposhita.

As the dhatus are basic element of the body and does the Dharana Of Sharir, asara dhatu fails in their functions and shows symptoms of pre mature aging.

Another Cause for premature Aging is Not Following Daily Regien which are told in ayurveda. (Ashtang Hruday/Sutrasthan/Dinacharya Adhyay)

Daily regimen or Dincharya plays major role in maintaining health of healthy individual. That's why it is mentioned under swasthvrutta upkram.

Some examples to see role of Dinacharya Apalan in Akaal Jarawastha.. a) If individual does not perform Abhyang told as daily regimen; he will not get the sneha ansha for twak and develops rukshata in twak. Further wrinkles can observed as symptom of premature aging.

Likewise it can be applicable for all processes told in Daily Regimen.

Similarly Sadvrutta Apalan also plays important role in premature aging.

- When the psychological initiation and control is disturbed, it results in a diseases.

- It is referred as 'Pradnyaparadha' in Ayurveda.

- 'Pradnyaparadh'(Intellectual Blasphemy)which is one of the three basic causes of the disease.

- Habit of suppression of any natural urge is a result of 'Pradnyaparadh'.

- Now a days Research has been carried to see role of stress in premature aging and it is proven that continuous stress leads to premature aging changes in body. It may shows graying of hairs, Dementia etc symptoms.

Lastly we head towards "Anukt Hetu Vichar" for Akaala Jarawastha

- Technology and its advancement brought a lot of changes to the lifestyle.

- Diseases and Health are related to food. Eating and Eating habits with wrong living pattern are considered crucial in Ayurveda. 
- Late Night Party, Nutrition less Food - Fast foods, Packed Food stuff etc, Working Pattern etc can affect on health. Gradually it shows premature aging changes as it does agni dushti.

\section{Discussion :}

Aging is one of the unavoidable processes occurring in each and every living being and one cannot prevent it. Classics have mentioned it as a Svabhavika Vyadhi (naturally occurring disease) because risk of developing various diseases increased in old age.

There is increase of Vata in old age, improper nourishment of Rasa Dhatu. The dependent Dhatus also undergo improper nourishment.

This process is gradual irreversible process of aging.

The Akaala Jara Samprapthi (aetiology of premature aging) can be briefly summarised as follows:

\section{$\underline{\text { Akaala Jara Samprapti }}$}

Nidanas (causative factors) such as Ati Ahara-Vihara

(excess food intake and improper lifestyle),

Manasika Vega Adhaarana (non-suppression of unpleasant

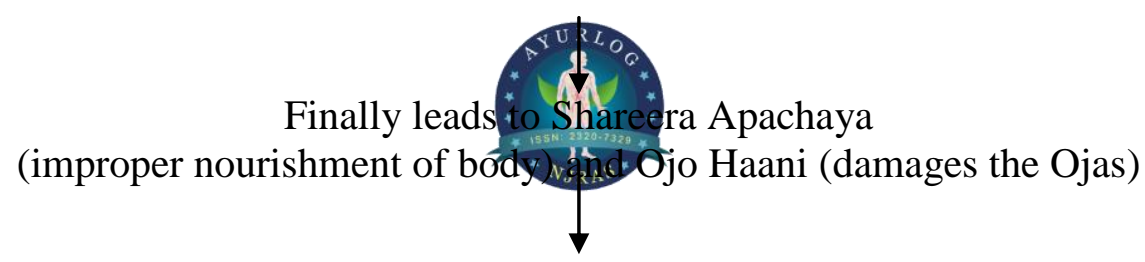

Akaala Jara (premature aging)

Srotolepa (blocks the body channels)

Agnimandya and Ama.

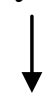

Then the function of Agni is vitiated

improper nourishment of Rasa and successive Dhatus.

\section{Conclusion:}

Kaalaja Jara (Chronological aging) is inevitable but one can delay the premature aging by following healthy life style.
Ayurveda is essentially the science of life and longevity. It presents a sound concept of aging; it has mentioned various measures among Dinacharya, Rutucharya 
and Sadvrutta which directly or indirectly work on delaying aging. There is

wide scope for Ayurveda in geriatric medicine as it has enriched knowledge of Rasayana Chikitsa.

Achary Atreya gives best example for how premature aging occurs in

Charak vimansthan Janapadudhwasniya adhyay.

He says,

An axel fitted in a vehicle which is endowed with all the natural qualities carries on and perishes in time by depreciation of its normal limit, similarly the life span in a body of a person having strong constitution and managed properly gets its end and loss of its normal limit. Such Death is known as timely, on other hand the same axel gets destroyed in the way due to overload, uneven road, want of road, breaking of wheels, defects in vehicle or driver, separation of bolt, non lubrication and throwing about, similarly the life span comes to an end in the middle due to over - exertion, diet not accordance with agni, irregular meals, complicated body postures, over indulgence in sexual activity, company of ignoble person, suppression of impelled urges, non suppression of suppresable urges, infliction with organisms, poisonous winds and fire, injury and avoidance of food and medications such death known as untimely.

This reference can applicable for timely aging and pre mature aging.

\section{References:}

1. Acharya JT. Sushruta Samhita with Nibandhasangraha commentary of Dalhana. Sutrasthana 24/7, Reprint edition. Varanasi (India): Chaukhambha Sanskrit Sansthan: 2009. P 114

2. ibid Charak Samhita Vimansthan Janapada Udhmasniya adhyay 37,38
3. Acharya JT. Charaka Samhita by Agnivesa with Ayurveda Deepika commentary of Chakrapani Datta, Sutrasthana 16/27-28, Reprint edition. Chaukhambha Prakashan, Varanasi (India): 2015. P 97

4. Acharya JT. Charaka Samhita by Agnivesa with Ayurveda Deepika commentary of Chakrapani Datta, Vimanasthana 3/32-35, Reprint edition. Chaukhambha Prakashan, Varanasi (India): 2015. P 243

5. Acharya JT. Charaka Samhita by Agnivesa with Ayurveda Deepika commentary of Chakrapani Datta, Shareerasthana 16/32, Reprint edition. Chaukhambha Prakashan, Varanasi (India): 2015. P 97

6. Bhat Shruthi N \& Rajashekhar K.N: Title Of The Article: Physiology Of Aging According To Ayurveda - A Review. International Ayurvedic Medical Journal \{online\} 2018 \{cited May, 2018\}

7. Charaka Samhita by Pradhyapak Vaidya Ya. Go. Joshi, $3^{\text {rd }}$ Eddition

8. Sarth Sushrut Samhita by vaidyaraj Datto Ballal Borkar

9. Review Article on Observational study on external social and lifestyle related factors and their role in pathogenesis of premature ageing and stress by Yogesh $\mathrm{S}$. Deole, Anup B. hakar, Harimohan Chandola, and B. Ravishankar. Viewed at Google Scholar https://www.ncbi.nlm.nih.gov/pmc/ articles/PMC3665085/

10. Review Article on THE CONCEPT OF AGING IN AYURVEDA by K. K. DWIVEDI, M. PAUL, P.B. BEHERE and R.H. SINGH, Department of Kayachikitsa and Psychiatry, Institute of Medical Sciences, Banaras Hindu University, Varanasi - 221005 , 
India. Viewed at Google Scholar https://www.researchgate.net/publi cation/224897856_The_concept_of aging_in_ayurveda
11. Charaka - Samhita (Text with English Translation), Chaukhamba Orientalia Publication by Prof. Priyavrat Sharma, Vol. 1

Cite article:

CAUSATIVE FACTORS FOR PREMATURE AGEING

Sameer Manohar Joshi, Gandhali Upadhye, Prathamesh Ajit Kotagi

Ayurlog: National Journal of Research in Ayurved Science- 2018; (6)(6): 1-6 